\title{
Efektivitas Teknik Antecedent Control dan Token Economy dalam Meningkatkan Durasi Perilaku Belajar pada Anak dengan Gangguan Intelektual Taraf Ringan
}

\author{
Effectiveness of Antecedent Control and Token Economy \\ Techniques to Enhance the Studying Duration for Children \\ with Mild Intellectual Disability
}

Lena, Dini P. Daengsari

Magister Profesi Psikologi Klinis Anak, Fakultas Psikologi, Universitas Indonesia Email: lim.lena28gmail.com

\begin{abstract}
KATA KUNCI perilaku belajar, gangguan intelektual taraf ringan, antecedent control, token economy

studying, mild intellectual disability, antecedent control, token

KEYWORDS economy
\end{abstract}

ABSTRAK

Perilaku belajar yang konsisten bagi anak dengan mild intellectual disability (MID) merupakan hal penting yang perlu dilakukan untuk dapat memaksimalkan kapasitas kemampuan anak, terutama dalam aspek konseptual. Belajar perlu di lakukan tidak hanya di sekolah, namun juga di rumah. Salah satu cara yang dapat dilakukan untuk menerapkan perilaku belajar di rumah adalah menggunakan teknik antecedent control dan token economy. Teknik antecedent control dapat dilakukan untuk mengontrol stimulus anteseden, sedangkan teknik token economy diterapkan untuk memanipulasi konsekuensi yang didapatkan dari munculnya perilaku. Penelitian ini bertujuan untuk mengetahui efektivitas penggunaan teknik antecedent control dan token economy dalam meningkatkan durasi perilaku belajar anak usia sekolah dengan MID. Metode penelitian terbagi menjadi 3 tahap, yaitu tahap baseline, intervensi, dan follow up yang dilakukan dalam 25 sesi pertemuan. Hasil penelitian menunjukkan bahwa terdapat peningkatan durasi perilaku belajar dari sesi baseline hingga sesi follow up. Ratarata durasi perilaku belajar anak dengan MID meningkat sebanyak 3 kali lebih lama, yaitu dari 22 menit menjadi 66,2 menit. Hasil penelitian membuktikan bahwa teknik antecedent control dan token economy cukup efektif dalam meningkatkan durasi perilaku belajar di rumah pada anak usia sekolah dengan MID, yang juga berimplikasi pada pengembangan kemampuan pemahaman aspek konseptual. Dengan demikian, teknik tersebut dapat menjadi alternatif intervensi yang bisa diterapkan oleh orangtua terhadap anak MID di rumah untuk mengoptimalkan kapasitas yang mereka miliki.

ABSTRACT Capability to study consistently is essential for children with MID so that they can fulfill their potential, especially in 
conceptual aspect. Studying should be performed not only at school, but at home as well. There are several behavior modification techniques that can be applied to develop studying habit, which are antecedent control and token economy. The antecedent control technique was used to control the antecedent stimulus, whether token economy was used as a form of manipulation to the consequence of behavior. This study aimed to investigate the effectiveness of antecedent control and token economy techniques to enhance the studying duration for schoolaged child with MID. Method of this study was divided into 3 steps, which are baseline (5 sessions), intervention (15 sessions), and follow-up (5 sessions). Results showed that there was an escalation of studying duration from baseline to follow-up sessions. The average of studying duration on follow-up session was 3 times longer compared to the baseline, which is from 22 minutes to 66.2 minutes. Such results indicate that antecedent control and token economy techniques is effective to enhance studying duration for school-aged child with MID, which implicating child's verbal comprehension skill. Therefore, this technique could be treated as alternate intervention to fulfil the potential of children with MID.

\section{PENDAHULUAN}

Gangguan intelektual atau intellectual disability (ID) dikarakteristikkan dengan adanya keterbatasan dalam fungsi intelektual dan fungsi adaptif. Keterbatasan dalam fungsi intelektual ditunjukkan oleh kapasitas intelektual (IQ) yang berada di bawah rata-rata, yaitu $\leq 70$, bila diukur melalui alat ukur inteligensi (American Psychiatric Association, 2013). Tingkat keparahan kondisi ID pada anak berdasarkan dukungan yang diperlukan terbagi menjadi empat, yaitu mild (mampu didik), moderate (mampu latih), severe dan profound (mampu rawat) (American Psychiatric Association, 2013; Sularyo \& Kadim, 2000).

Estimasi prevalensi kemunculan kondisi ID pada anak di dunia berkisar antara 8,7 36,8 per 1.000 (Boat \& Wu, 2105). Lebih lanjut, prevalensi untuk kondisi ID pada anak ditemukan cenderung lebih tinggi pada tingkat mild, yakni sebesar $2-30$ per 1.000. Di Indonesia, berdasarkan hasil Pendataan Program Perlindungan Sosial tahun 2011 (dalam Kementrian Kesehatan RI, 2014) ditemukan bahwa sekitar 30.460 anak memiliki gangguan ID. Sama halnya dengan prevalensi dunia, kondisi mild-ID (MID) pada anak di Indonesia ditemukan lebih tinggi dibandingkan kondisi lainnya (Maramis, dalam Pratiwi, Handayani, \& Raharjo, 2017).

Tingginya prevalensi ID dengan kondisi mild pada anak memerlukan perhatian khusus dari praktisi anak. Hal ini dikarenakan anak dengan MID biasanya lebih lambat teridentifikasi dibandingkan kondisi ID-lainnya. Orangtua baru menyadari kondisi MID pada anak di usia sekolah karena mereka mulai mengalami kesulitan dalam menghadapi proses pembelajaran akademik, seperti membaca, menulis, atau berhitung (Boat $\& \mathrm{Wu}, 2015$ ). Keterlambatan identifikasi kondisi MID pada anak membuat perlu adanya penanganan segera untuk dapat mengoptimalkan kapasitas yang mereka miliki.

Mangunsong (2009) menjelaskan bahwa anak dengan ID, termasuk MID di usia sekolah memiliki hambatan dalam kinerja akademis. Masalah akademis tersebut menjadi aspek yang penting untuk 
diberikan penanganan intervensi karena anak dengan MID tergolong kategori mampu didik yang membuat mereka memiliki potensi untuk mengembangkan kapasitasnya konseptualnya dalam bidang akademis setara dengan anak sekolah dasar (American Psychiatric Association, 2013). Jansen, Lange, dan van der Molen (2013) menjelaskan bahwa penguasaan konseptual dasar sangat penting untuk anak tipikal maupun anak dengan gangguan perkembangan seperti MID. Kemampuan konseptual, seperti membaca, menulis, berhitung, pengenalan waktu, uang, dan sebagainya merupakan kemampuan dasar yang dibutuhkan untuk melatih kemandirian anak dalam kehidupan seharihari untuk saat ini maupun masa yang akan datang, misalnya untuk mendapatkan pekerjaan (Butler, Miller, Lee, \& Pierce, 2001).

Optimalisasi pengembangan kapasitas kemampuan pada anak dengan MID dibutuhkan pengulangan yang konsisten terhadap hal-hal yang dipelajarinya (Allor, Champlin, Gifford, \& Mathes, 2010). Kondisi tersebut mengindikasikan bahwa pengajaran konseptual pada anak MID tidak hanya terjadi di lingkungan sekolah, namun juga perlu dilakukan di lingkungan rumah. Meski demikian, anak MID seringkali menampilkan perilaku belajar yang buruk. Masalah perilaku belajar yang buruk terbagi menjadi tiga kategori (Gage \& Berliner, 1992; Soemanto, 1998) yaitu (1) terlalu banyak munculnya perilaku yang tidak diharapkan ketika sedang belajar (contoh: berjalan-jalan, berbicara, dll); (2) terlalu sedikit munculnya perilaku yang diharapkan ketika sedang belajar (contoh: sulit memusatkan perhatian, tidak berminat terhadap tugas, dll); (3) terlalu sedikitnya waktu yang dugunakan untuk belajar (contoh: kegiatan belajar dilakukan dalam waktu singkat, belajar tidak teratur, menunda waktu belajar). Perilaku belajar yang buruk ini dapat terjadi pada anak dengan MID karena mereka memiliki kecenderungan kurang dapat melakukan perencanaan dan cara belajar yang tepat
(Astati, 2001) sehingga pada akhirnya berkontribusi pada kurangnya kesadaran untuk merencanakan kegiatan belajar dan mengerjakan tugas.

Faktor lain yang dapat berkontribusi terhadap munculnya masalah perilaku belajar yang buruk pada anak MID adalah tingkat status sosial ekonomi (SSE) keluarga. Boat dan Wu (2015) menjelaskan bahwa prevalensi anak MID cenderung lebih banyak berasal dari SSE yang rendah. Kondisi ini membuat anak MID kurang mendapatkan stimulasi yang memadai untuk mengembangkan perilaku belajar yang baik untuk mengoptimalkan kemampuannya. Selain itu, orangtua yang memiliki anak MID dan berasal dari SSE rendah cenderung kurang menerapkan aturan di rumah dan memantau kegiatan yang dilakukan oleh anaknya (Schuiringa, van Nieuwenhuijzen, de Castro, \& Matthys, 2015). Hal ini semakin menurunkan kesadaran anak untuk menampilkan kegiatan belajar di rumah untuk mengulang materi yang telah dipelajari di sekolah. Maka dari itu, diperlukan intervensi terhadap perilaku belajar anak MID di rumah yang diharapkan dapat meningkatkan kemampuan konseptual mereka dan meminimalkan hambatan performa akademik di sekolah. Penanganan yang dapat dilakukan adalah mengembangkan kebiasan belajar di rumah. (Mohsin, Khan, Doger, \& Awan, 2011).

Terdapat beberapa intervensi yang dapat dilakukan untuk membantu pengembangan kemampuan pada anak dengan disabilitas yaitu peer tutors, teknologi, dan applied behavior analysis (ABA) (Browder, Wood, Thompson, \& Ribuffo, 2014). Intervensi peer tutors dapat digunakan oleh orangtua untuk mengembangkan kebiasaan belajar anak MID di rumah, namun intervensi ini membutuhkan rangkaian yang panjang karena diperlukan pelatihan terlebih dahulu kepada teman yang ditunjuk sebagai tutor (Heron, Villareal, Yaoi, Christianson, \& Heron, 2006). Untuk intervensi menggunakan teknologi dibutuhkan biaya lebih untuk menyediakan media elektronik 
yang sesuai dengan kebutuhan anak (Kagohara et al., 2011), sedangkan mayoritas anak MID berasal dari SSE yang rendah sehingga intervensi ini dinilai kurang tepat. Dengan demikian, intervensi yang mungkin dapat dilakukan oleh orangtua di rumah adalah melalui pendekatan ABA.

Metode ABA merupakan pelatihan yang berfokus pada hubungan sistematis antara tingkah laku dengan lingkungan, yang berupa anteseden (peristiwa yang terjadi sebelum munculnya tingkah laku) dan konsekuensi (peristiwa setelah munculnya tingkah laku) (Kazdin, 2013). Berdasarkan penjelasan tersebut, prinsip teknik dalam metode ABA yang dapat dilakukan oleh orangtua adalah dengan menerapkan kombinasi antara anteseden dan konsekuensi melalui teknik antecedent control dan token economy dalam membentuk perilaku belajar anak MID di rumah (Athens, Vollmer, \& Pipkin, 2007; Mirzamani, Ashoori, \& Sereshki, 2011).

Soemanto (1998) menjelaskan bahwa perilaku belajar terbagi menjadi beberapa aktivitas, yakni membaca, menulis/mencatat, dan latihan. Pertama, membaca dalam aktivitas belajar harus mempunyai tujuan dan rencana (dimulai dari tema umum ke tema yang lebih khusus). Selain itu, membaca juga berkaitan dengan kegiatan mencatat yang memudahkan anak untuk mengingat kembali isi bacaan. Kedua, anak menuliskan materi sesuai dengan kebutuhan dan tujuannya, serta dapat menggunakan catatan tersebut untuk pencapaian tujuan belajar. Terakhir, latihan adalah usaha integratif dan terarah pada suatu tujuan untuk dapat melakukan suatu hal yang telah dipelajari atau mengasah kemampuan terhadap pemahaman materi.

Kurangnya perilaku belajar di rumah bagi anak MID dianggap sebagai perilaku yang defisit dan merugikan bagi perkembangan kapasitas kemampuan mereka. Mohsin dkk (2011) menjelaskan bahwa untuk memaksimalkan kemampuan anak untuk keterbatasan intelektual dapat dilakukan melalui peningkatan durasi belajar yang lebih lama. Perilaku belajar yang secara konsisten ditunjukkan dalam durasi waktu tertentu dapat meningkatkan pemahaman konseptual bagi anak. Maka dari itu, perlu diwujudkan perilaku belajar dalam bentuk membaca buku pelajaran / catatan, menulis / menyalin catatan, dan mengerjakan latihan soal pada durasi waktu tertentu di rumah terhadap anak MID melalui intervensi untuk membantu mengoptimalkan kemampuan yang dimiliki.

Intervensi melalui metode ABA dapat dilakukan dengan melakukan teknik antecedent control dan token economy. Penerapan teknik antecedent control dapat dilakukan dengan mengontrol mengantisipasi anteseden stimulus yang menyebabkan kemunculan suatu perilaku (Miltenberger, 2012). Salah satu strategi yang dapat diterapkan adalah dengan menyediakan anteseden stimulus dari target perilaku. Strategi ini dapat dilakukan orangtua dengan menentukan jadwal jam belajar yang konsisten setiap harinya (Martin \& Pear, 2015). Jadwal jam belajar dapat didiskusikan melalui kesepakatan antara orangtua dan anak, sehingga anak diharapkan dapat menampilkan perilaku belajar diwaktu yang telah disepakati. Kontrol anteseden lain yang dapat dilakukan adalah dengan menyediakan tugas soal untuk anak (Short, 2016). Hal ini secara tidak langsung mendorong anak untuk menampilkan perilaku belajar. Penyediaan tugas soal dapat disediakan oleh orangtua atau melalui koordinasi dengan guru di sekolah. Selain itu, orangtua juga perlu mengontrol situasi kondisi belajar dengan menyediakan ruangan yang nyaman dan tidak bising, serta peralatan belajar yang dibutuhkan oleh anak (Martin \& Pear, 2015). Hal ini guna meningkatkan atensi dalam belajar.

Selanjutnya, teknik token economy diterapkan dengan cara memberikan token terhadap setiap kemunculan perilaku yang diharapkan dan akumulasi token tersebut dapat ditukarkan dalam back reinforcer 
(Miltenberger, 2012). Token dapat berupa stiker, koin atau apapun benda yang disenangi oleh anak. Token akan diberikan setiap kali anak menampilkan target perilaku yang diharapkan, yaitu dalam penelitian ini berupa perilaku belajar di rumah. Pengumpulan token dapat ditukarkan dengan backup reinforcer yang diberikan dalam bentuk consumable reinforcer (contoh: permen; susu) atau hal lain yang disukai anak. Backup reinforcer menjadi motivasi bagi anak MID untuk dapat menampilkan target perilaku yang diharapkan (Aziz \& Yasin, 2018). Maka dari itu, penelitian ini bertujuan untuk menerapkan intervensi dengan teknik modifikasi perilaku antecedent control dan token economy untuk meningkatkan durasi perilaku belajar dalam bentuk bentuk membaca buku pelajaran / catatan, menulis / menyalin catatan, dan mengerjakan latihan soal di rumah pada anak dengan MID.

\section{METODE}

\section{Partisipan}

Karakteristik partisipan penelitian ini adalah anak usia sekolah dengan diagnosa gangguan intelektual dengan tingkat keparahan mild (MID). Partisipan dalam penelitian ini berjumlah satu orang dengan inisial S, anak perempuan yang berusia 10 tahun delapan bulan. $\mathrm{S}$ telah melakukan pemeriksaan psikologis dan didiagnosa MID dengan kapasitas intelektual (IQ) sebesar 53.

S merupakan siswa kelas lima SD di sekolah reguler, sehingga sehari-harinya ia mengikuti materi pembelajaran sesuai dengan anak tipikal seusianya yang tidak memiliki masalah perkembangan. Hal ini membuat $\mathrm{S}$ perlu mempersiapkan diri untuk mengikuti ujian akhir sekolah saat ia naik ke jenjang pendidikan kelas enam SD. Sedangkan sehari-harinya di rumah, S tidak memiliki jadwal kegiatan belajar yang konsisten dan lebih banyak menghabiskan waktunya untuk bermain. Hingga saat ini, ia juga belum pernah menerima intervensi apa pun. Maka dari itu, orangtua $\mathrm{S}$ bersedia untuk mengikuti penelitian ini agar dapat menetapkan kegiatan belajar konsisten yang dapat membantu $\mathrm{S}$ dalam mempersiapkan diri menghadapi materi akademis di sekolah.

\section{Desain Penelitian}

Penelitian ini menggunakan desain penelitian single subject $A-B$ design, yakni hanya memiliki satu subjek $(\mathrm{N}=1)$. Desain ini umumnya digunakan untuk mengukur perubahan perilaku spesifik individu dari hasil intervensi yang diterapkan. Desain penelitian ini menggunakan data pretest posttest yang diterapkan dengan membandingkan penggukuran data partisipan sebelum diberikan intervensi dan setelah diberikan intervensi (Kazdin, 2013)

\section{Metode pengambilan data}

Metode pengambilan data dalam penelitian ini menggunakan wawancara dan observasi. Wawancara dilakukan kepada Ibu $\mathrm{S}$ untuk mengetahui perilaku belajar subjek di rumah sehari-hari, sebelum intervensi dilakukan. Selanjutnya, metode observasi dilakukan secara langsung oleh peneliti dalam menghitung jumlah durasi waktu yang dihabiskan oleh $\mathrm{S}$ dalam melakukan kegiatan mengerjakan tugas latihan soal, membaca dan menulis catatan.

\section{Setting Penelitian}

Intervensi program dilakukan di rumah anak. Ruangan yang digunakan untuk intervensi adalah ruangan belajar anak. Peralatan yang digunakan dalam intervensi ini adalah meja belajar, alat tulis, buku catatan dan pelajaran, serta tugas soal dari guru di sekolah.

\section{Prosedur Penelitian}

Prosedur penelitian pada penelitian ini terbagi menjadi tiga, yaitu tahap persiapan, tahap pelaksanaan, dan tahap tindak lanjut. Pada tahap persiapan, peneliti melakukan analisis kebutuhan kepada orangtua melalui wawancara orangtua dan observasi pada anak. Hasil wawancara dan observasi menunjukkan kurangnya durasi belajar di rumah pada anak. Selain itu, wawancara 
dan observasi juga dilakukan untuk mengetahui jenis reinforcement yang disukai oleh anak agar dapat digunakan selama intervensi. peneliti

Selanjutnya, peneliti melakukan studi literatur terkait dan konsultasi kepada psikolog anak dalam merancang modul program intervensi. Peneliti kemudian memberikan informed consent kepada partisipan dan orangtuanya dalam mengikuti program penelitian ini. Setelah itu, peneliti melakukan baseline sebanyak lima sesi (satu sesi/hari) melalui wawancara ibu terhadap hasil pengamatannya berdasarkan lembar observasi yang diberikan.

Kedua, tahap pelaksanaan. Program intervensi dilaksanakan selama 15 sesi. Terakhir, tahap tindak lanjut dilakukan sebanyak lima sesi. Tahap tindak lanjut dilakukan setelah enam minggu setelah intervensi diberikan untuk menentukan apakah perubahan yang dicapai selama program dapat dipertahankan setelah program usai.

\section{Program Intervensi}

Program intervensi modifikasi perilaku dilakukan dalam 15 sesi yang tebagi menjadi tiga fase. Pembagian fase dalam tahap intervensi dilandaskan durasi perilaku belajar, yaitu 30 menit untuk fase satu, 45 menit untuk fase dua, dan 60 menit untuk fase tiga (Zulhaqqi, 2016). Program modifikasi pada penelitian ini menggunakan teknik antecedent control yang diterapkan dengan membuat kesepakatan antara orangtua, peneliti, dan $S$ mengenai jadwal jam belajar yang akan dilakukan di rumah. Penerapan antecedent control lainnya adalah pemberian materi dari guru pendamping sebagai tugas pekerjaan rumah bagi S. Selain itu, teknik token economy diaplikasikan dengan cara memberikan poin dalam bentuk stiker pada kemunculan perilaku belajar sesuai dengan target durasi. Selain itu, satu poin tambahan akan diberikan bila $\mathrm{S}$ mengerjakan latihan soal dengan target soal yang benar 50\% $75 \%$ (misalnya 6 jawaban benar dari 10 soal) atau dua poin untuk target soal yang benar $>75 \%$ (misalnya delapan jawaban benar dari 10 soal). S dapat menukarkan poin yang dikumpulkan dengan backup reinforcer di akhir minggu, berupa minuman atau makanan ringan. Selain itu, $\mathrm{S}$ juga mendapatkan positive reinforcement dalam bentuk social reinforcer (memberikan pujian, pelukan, dan lain sebagainya) setiap kali mencapai durasi target perilaku.

Peneliti dalam tahap intervensi berperan untuk mengkondisikan $\mathrm{S}$ dalam ruangan belajar yang tidak bising dan memberikan instruksi untuk memulai kegiatan belajar sesuai dengan jadwal yang telah disepakati bersama. Selain itu, peneliti juga menjadi fasilitator dalam kegiatan belajar, bila $\mathrm{S}$ menemui kesulitan dengan materi pelajarannya. Pada setiap akhir sesi, peneliti menghitung jumlah durasi waktu belajar $S$ dan memberikan token sesuai dengan target perilaku yang ditampilkan. Setiap akhir fase intervensi (fase satu, dua, dan tiga), peneliti memfasilitasi penukaran token yang telah dikumpulkan selama lima sesi dengan backup reinforcer.

Terakhir, tahap follow up dilakukan enam minggu setelah program modifikasi perilaku diberikan. Hal ini dilakukan untuk melihat perubahan perilaku anak yang dicapai selama tahap intervensi dapat dipertahankan atau tidak setelah progam selesai. Berikut ini adalah uraian tahapan, sesi dan teknik yang digunakan dalam penelitian ini:

Tabel 1

Tahapan Intervensi

\begin{tabular}{ccl}
\hline Tahap & $\begin{array}{c}\text { Jumlah } \\
\text { Sesi }\end{array}$ & \multicolumn{1}{c}{ Teknik } \\
\hline Baseline & 5 & $\begin{array}{l}\text { *Setting: aktivitas } \\
\text { belajar sehari-hari di } \\
\text { rumah. }\end{array}$ \\
\hline
\end{tabular}




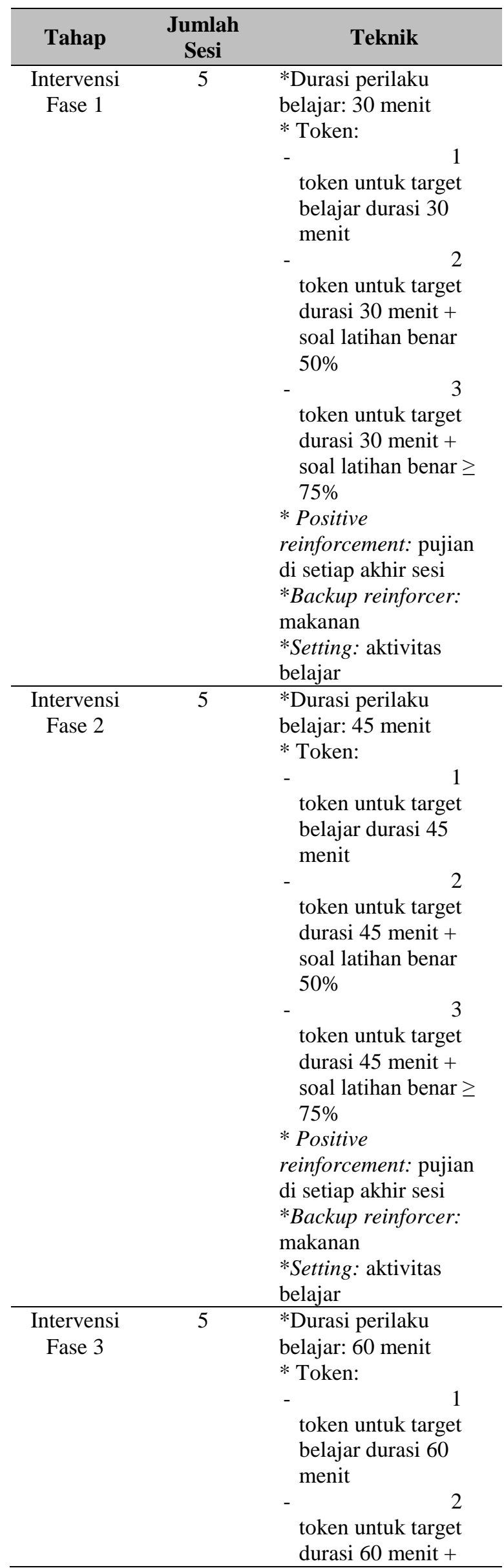

\begin{tabular}{ccc} 
Tahap & $\begin{array}{c}\text { Jumlah } \\
\text { Sesi }\end{array}$ & \multicolumn{1}{c}{ Teknik } \\
& & soal latihan benar \\
& $50 \%$ & 3 \\
& & token untuk target \\
& durasi 60 menit + \\
& soal latihan benar $\geq$ \\
& $75 \%$ \\
& $*$ Positive \\
& reinforcement: pujian \\
& di setiap akhir sesi \\
& $*$ Backup reinforcer: \\
& makanan \\
& * Setting: aktivitas \\
& belajar \\
\hline & * Setting: aktivitas \\
& belajar sehari-hari di \\
& rumah. \\
\hline
\end{tabular}

\section{Teknik Analisis Data}

Metode analisis data yang dilakukan dalam penelitian ini adalah teknik statistik deskriptif dengan menggunakan grafik. Analisis data didapatkan dengan membandingkan durasi perilaku belajar di rumah sebelum diberikan intervensi dan setelah diberikan intervensi. Kratochwill dkk (2010) menjelaskan bahwa terdapat fitur analisis visual yang dapat digunakan untuk single case design diantaranya adalah level dan trend. Analisa level dilakukan dengan membandingkan rata-rata pada setiap tahapan, sedangkan trend dilakukan dengan melihat persebaran data pada grafik melalui garis trend (trendline).
ANALISIS DAN HASIL
Hasil rata-rata durasi perilaku belajar $\mathrm{S}$ di rumah selama lima sesi pada tahap baseline adalah 22 menit. Durasi terlama $\mathrm{S}$ menunjukkan perilaku belajar adalah 30 menit dan durasi tersingkat adalah 20 menit. Ibu $\mathrm{S}$ menjelaskan bahwa $\mathrm{S}$ hanya menampilkan perilaku membaca buku selama tahap baseline. Perilaku tersebut juga tidak secara serius ditunjukkan oleh $\mathrm{S}$. Ia membaca buku sambil sesekali menonton televisi atau bercanda dengan adiknya. Terkadang, ia tidak menyelesaikan suatu bacaan dan berpindah ke bacaan lainnya.
Penelitian dilanjutkan ke tahap intervensi sebanyak 15 sesi yang dilakukan 
selama tiga minggu. Semua sesi dilakukan di rumah subjek, tepatnya pada ruang tamu dan dilakukan selama kurang-lebih 30 hingga 60 menit pada rentang waktu 15.30 17.00. Rentang waktu tersebut adalah waktu dimana $S$ telah pulang sekolah. Peneliti bertugas menjalankan program hingga sesi ke 12, sedangkan sesi ke 13 hingga ke 15 dijalankan oleh Ibu S. Selama pelaksanaan program, Ibu bersikap kooperatif dengan jadwal yang telah disusun sehingga kegitan pembelajaran rutin dijalankan.

Berikut adalah grafik durasi perilaku belajar yang ditunjukkan oleh $\mathrm{S}$ dari sesi baseline hingga sesi intervensi.

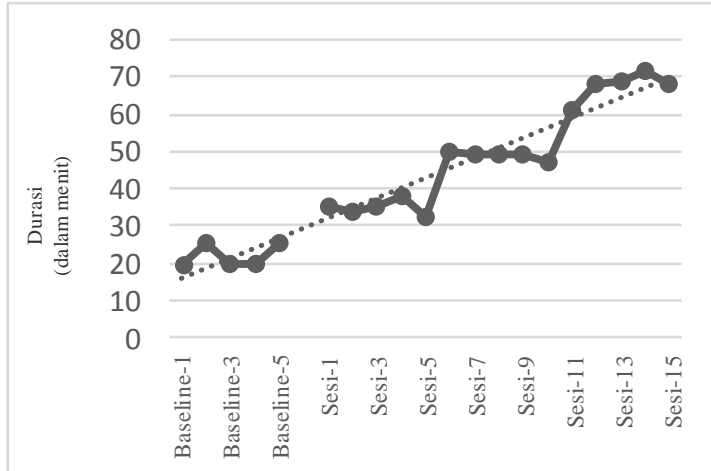

Gambar 1

Grafik Durasi Perilaku Belajar

Berdasarkan grafik di atas, terlihat peningkatan durasi belajar pada S. Rata-rata durasi perilaku belajar pada tahap baseline adalah 22 menit, sedangkan pada tahap intervensi meningkat menjadi 50,4 menit. Hasil tersebut menunjukkan durasi perilaku belajar dua kali lebih lama pada tahap intervensi dibandingkan tahap baseline. Selain itu, dalam grafik terlihat garis trend yang naik dari tahap baseline ke tahap intervensi yang mengindikasikan adanya peningkatan durasi belajar yang signifikan pada S. Dengan demikian dapat disimpulkan bahwa teknik antecedent control dan token economy berhasil membantu meningkatkan durasi perilaku belajar pada anak dengan MID.

Merujuk pada grafik diatas, terdapat adanya penurunan durasi perilaku belajar pada akhir setiap tahap, yaitu sesi ke 5, ke 10, dan ke 15. Hal ini mungkin disebabkan oleh pengulangan materi tugas soal yang konsisten pada setiap tahap, sehingga pemahamannya semakin meningkat dan membutuhkan waktu yang lebih cepat untuk mengerjakan soal-soal tugas.

Hasil peningkatan durasi perilaku belajar yang ditunjukkan oleh $\mathrm{S}$ dapat disebabkan oleh antecedent control yang tepat dengan kebutuhannya, pemberian token economy dan back-up reinforcer yang konsisten dan efektif, serta pujian dari Ibu mengenai kebiasaannya menampilkan perilaku belajar setiap hari. Antecedent control berupa jadwal belajar, pemberian tugas, dan kondisi ruangan belajar yang jauh dari kebisingan menjadi hal yang cukup berpengaruh terhadap munculnya perilaku belajar pada S. Dengan adanya pemberian tugas yang berkala membuat $S$ harus mengerjakan tugas tersebut dan konsisten mengerjakannya pada jadwal belajar yang telah ditentukan. Pemberian token economy dan back-up reinforcer membuat $S$ lebih bersemangat untuk mengerjakan tugas karena ia dapat memperoleh makanan ringan yang disukai. Disamping itu, pemberian pujian dari Ibu juga mengubah suasana belajar lebih menyenangkan bagi $\mathrm{S}$ karena sebelumnya beliau cenderung bersikap tak acuh dengan kegiatan tersebut. Berbagai hal tersebut membuat $S$ lebih bersemangat dan konsisten untuk menampilkan perilaku belajar di rumah.

S mampu menjalankan program modifikasi perilaku sesuai dengan target yang telah ditentukan dalam penelitian ini dengan mengalokasikan waktunya selama 30 menit hingga 60 menit untuk melakukan kegiatan belajar yang terdiri dari menulis dan membaca catatan, serta mengerjakan tugas-tugas soal. Walaupun mampu mencapai durasi target perilaku, $\mathrm{S}$ menampilkan sikap kerja yang berbeda pada setiap kegiatan perilaku belajar. $S$ cenderung memilih mengawali kegiatan dengan mengerjakan tugas. Pada sesi awal, ia lebih bersikap pasif dan menunjukkan rasa frustasinya saat mengerjakan soal yang dianggap sulit. Setelah mendapatkan 
bimbingan, $\mathrm{S}$ dapat mengerjakan tugas secara mandiri dan mampu mempertahankan atensi dalam jangka waktu yang lama secara konsisten.

Sikap kerja $\mathrm{S}$ dalam kegiatan menulis diawal tahap intervensi cenderung bermalas-malasan dan membuat beberapa kesalahan. Ia seringkali membolak-balik buku pelajaran tanpa tujuan, menuliskan catatan dengan posisi tidur-tiduran di meja, melewati beberapa informasi yang perlu dicatat, atau mencampurkan beberapa informasi dalam satu nomor. Dari pertengahan hingga akhir sesi, S menampilkan sikap yang lebih atentif dan tidak membuat kesalahan yang signifikan seperti sebelumnya, dalam menuliskan catatan.

Berbeda halnya dalam kegiatan membaca catatan, $\mathrm{S}$ seringkali menampilkan perilaku off task pada kegiatan ini. Ia cenderung berpindah posisi duduk, tidur-tiduran di lantai, membolakbalik buku, atau menopang kepalanya ke tangan. Ia juga seringkali mengaku telah selesai membaca, namun tidak dapat menjelaskan intisari dari bacaan. Hal ini membuat Ibu perlu seringkali menegur dan mengingatkan $S$ untuk membaca dengan serius. Meski telah berulang kali ditegur, $\mathrm{S}$ tidak menampilkan perubahan sikap kerja yang lebih baik dalam kegiatan membaca catatan hingga tahapan intervensi berakhir.

Perbedaan sikap kerja yang ditampilkan $\mathrm{S}$ dalam setiap kegiatan belajar dapat disebabkan oleh minat belajar dan tingkat kesulitan yang berbeda terhadap ketiga kegiatan tersebut Selain itu, perolehan tambahan token stiker dalam kegiatan mengerjakan tugas dapat menjadi motivasi bagi $\mathrm{S}$ untuk menampilkan sikap kerja yang lebih baik dalam kegiatan tersebut. Hal ini dikarenakan tambahan token stiker dapat memperbesar peluangnya untuk memilih jenis makanan yang disukai.

Tahap follow up dilaksanakan enam minggu setelah program modifikasi perilaku dilaksanakan. Tahapan ini dilakukan untuk mengetahui apakah durasi perilaku belajar pada $S$ dapat bertahan atau tidak, setelah program intervensi selesai dilaksanakan. Tahap follow up dilakukan sebanyak lima sesi, seperti yang dilakukan pada tahap baseline. Berikut adalah hasil durasi perilaku belajar S selama sesi follow up

Tabel 2

\begin{tabular}{ccccc} 
Hasil Follow Up & \multicolumn{3}{c}{} \\
\hline \multirow{2}{*}{$\begin{array}{c}\text { Follow } \boldsymbol{U p} \\
\text { Sesi ke- }\end{array}$} & \multicolumn{4}{c}{ Jumlah waktu (menit) } \\
\cline { 2 - 5 } & Baca & Tulis & Soal & Total \\
\hline 1 & 17 & 14 & 34 & 65 \\
2 & 20 & 11 & 37 & 68 \\
3 & 19 & 17 & 35 & 71 \\
4 & 18 & 14 & 31 & 63 \\
5 & 23 & 13 & 28 & 64 \\
\hline
\end{tabular}

Pada tahap follow up ini, S selalu memberitahukan kepada Ibu mengenai tugas yang diberikan oleh guru pendamping di sekolah yang merupakan bagian kontrol anteseden dalam program modifikasi perilaku ini. Ia segera menyiapkan peralatan belajarnya di ruang tamu, setelah mendapatkan instruksi dari Ibu untuk mengerjakan tugasnya setelah mandi sore dan ibadah sholat.

$S$ dapat mempertahankan atensinya dalam mengerjakan tugas. Ia juga menunjukkan insiatif untuk bertanya kepada Ibu bila kesulitan menjawab soal pertanyaan. Dalam kegiatan membaca, $S$ menunjukkan sikap yang lebih baik dibandingkan pada saat intervensi. Ia dapat duduk tenang untuk membaca catatan yang telah dituliskannya. Hal ini juga dapat disebabkan oleh modifikasi pembelajaran yang dilakukan oleh Ibu dengan meminta $S$ untuk menjelaskan bacaannya per nomor. Beberapa kali dalam kegiatan menulis, $\mathrm{S}$ menampilkan sikap tidur-tiduran di meja sambil menuliskan catatan di meja. Meski demikian, ia tetap menyelesaikan bagian informasi yang perlu dicatat dari buku sesuai dengan yang diinstruksikan oleh Ibu.

Berikut penjabaran perbandingan ratarata durasi perilaku belajar pada $S$ saat tahap baseline, tahap intervensi, dan tahap follow-up: 


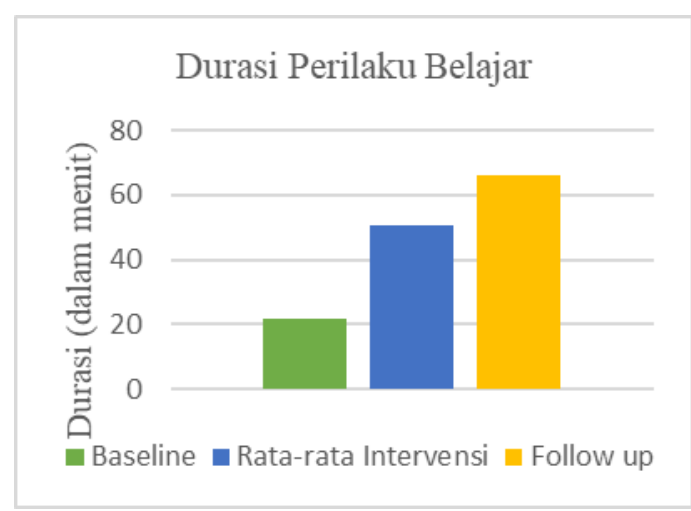

Gambar 2

Perbandingan Hasil Intervensi

Berdasarkan grafik di atas dapat disimpulkan bahwa durasi perilaku belajar $\mathrm{S}$ setiap harinya dapat bertahan setelah program intervensi berakhir. Durasi perilaku belajar $\mathrm{S}$ yang minim sebelum intervensi (tahap baseline), yakni 22 menit, kini dapat meningkat hingga 66,2 menit pada tahap follow up. Hasil tersebut dapat dicapai oleh $\mathrm{S}$ meskipun tanpa diberikan token economy ataupun back-up reinforce secara berkala.

\section{DISKUSI}

Hasil penelitian membuktikan adanya peningkatan durasi perilaku belajar di rumah pada anak usia sekolah dengan MID menggunakan teknik antecedent control dan token economy. Keberhasilan kedua teknik tersebut dapat dikarenakan penggunaan teknik yang berfokus pada kontrol anteseden (antecedent control) yang menstimulasi kemunculan perilaku belajar dan konsekuensi (token economy) yang diterima oleh anak bila menampilkan perilaku belajar tersebut. Kern, Choutka, dan Sokol (2002) mengemukakan bahwa stimulus anteseden berperan sebagai pendorong munculnya suatu perilaku, maka dengan melakukan kontrol terhadap stimulus anteseden, perilaku individu dapat diantisipasi kemunculannya. Dalam penelitian ini, dengan adanya kontrol pemberian tugas, jadwal belajar, serta penyediaan ruangan belajar, maka dapat memunculkan perilaku belajar di rumah. Di sisi lain, penerapan teknik token economy juga menciptakan motivasi yang berkembang menjadi asosiasi positif menyenangkan bagi anak dengan keterbatasan intelektual untuk menampilkan perilaku belajar (Aziz \& Yasin, 2018).

Perilaku belajar yang ditampilkan oleh $S$ juga menunjukkan hasil tambahan lain, yakni penguasaan terhadap materi tugas matematika berupa pengurangan dan perkalian. Hal ini terlihat dari perolehan tambahan token yang konsisten dari sesi ke8 hingga sesi ke-15, maka dapat diasumsikan $\mathrm{S}$ mulai menguasai materi tugas yang dikerjakanannya. Hasil ini sejalan dengan penjelasan Mohsin, dkk. (2011) bahwa anak dengan keterbatasan intelektual dapat meningkatkan pemahaman konseptualnya melalui perilaku belajar dengan durasi waktu yang panjang dan konsisten.

Hasil lain yang ditemukan dalam program ini adalah sikap bermalas-malasan $S$ dalam kegiatan membaca dan mempaparkan intisari bacaa yang ditunjukkan dalam bentuk membolak-balik buku tanpa tujuan, tidur-tiduran di lantai atau berpindah posisi duduk. Munculnya sikap tersebut dapat disebabkan oleh minatnya yang rendah terhadap kegiatan tersebut atau kapasitas intelektualnya yang terbatas sehingga tidak memahami bacaan. Murray, Mitchell, Gale, Edwards, dan Zyngier (2004) menjelaskan kedua faktor tersebut dapat menjadi faktor risiko munculnya disengagement terhadap perilaku belajar dalam bentuk perilaku disruptif (misalnya tidak fokus dengan kegiatan yang dilakukan atau berpindah dari posisi duduknya), seperti halnya yang ditampilkan oleh S. Masalah ini menjadi kelemaham dalam program intervensi ini dan dijadikan pertimbangan untuk perbaikan program selanjutnya yang akan dibahas pada bagian saran.

\section{SIMPULAN}

Berdasarkan penjelasan di atas, dapat disimpulkan bahwa program modifikasi perilaku dengan teknik antecedent control dan token economy terbukti efektif dalam 
meningkatkan durasi perilaku belajar di rumah pada anak MID. Penggunaan kedua teknik tersebut dapat membantu anak MID untuk mengembangkan kemampuan pemahaman konseptualnya.

\section{SARAN}

Pada penelitian selanjutnya disarankan menggunakan A-B-A-B design dan jumlah partisipan lebih dari satu agar hasil penelitian yang didapatkan lebih ajeg dan dapat digeneralisasikan untuk berbagai usia. Selain itu, terkait program intervensi disarankan mendiskusikan materi pemebelajaran kepada guru pendamping di sekolah. Selanjutnya, pemberian tambahan token lebih baik diberikan pada setiap kegiatan membaca catatan, menulis catatan, dan mengerjakan tugas. Hal ini dilakukan agar anak tidak hanya berfokus pada salah satu perilaku belajar yang mendapatkan tambahan poin, lalu mengabaikan perilaku belajar lainnya. Dengan demikian, diharapkan anak dapat menampilkan sikap kerja yang positif diseluruh kegiatan perilaku belajar. Terakhir, memberikan waktu istirahat selama $5-10$ menit pada setiap perpindahan kegiatan belajar. Waktu istirahat diberikan untuk mengurangi rasa jenuh yang dalam kegiatan belajar dan menghindarai sikap bermalas-malasan pada kegiatan belajar selanjutnya.

\section{DAFTAR PUSTAKA}

Allor, J. H., Champlin, T. M., Gifford, D. B., \& Mathes, P. G. (2010). Methods for increasing the intensity of reading instruction for students with intellectual disabilities. Education and Training in Autism and Development Disabilities, 45(4), 500-511.

American Psychiatric Association. (2013). Diagnostic and statistical manual of mental disorder (5th ed.). Washington, DC, USA: Author.

Astati. (2001). Persiapan pekerjaan penyandang tunagrahita. Bandung: CV. Pandawa.

Athens, E. S., Vollmer, T. R., \& Pipkin, C. C. S. P. (2007). Shaping academic task engagement with percentile schedules. Journal of Applied Behavior Analysis, 40,
475-488.

Aziz, N. A. A., \& Yasin, M. H. M. (2018).

Token economy to improve concentration among students with learning disabilities in primary school. Journal of ICSAR, 2(1), 32-36.

Boat, T. F., \& Wu, J. T. (2015). Mental disorders and disabilities among lowincome children. Washington, DC: The National Academies Press.

Butler, F. M., Miller, S. P., Lee, K., \& Pierce, T. (2001). Teaching mathematics to students with mild-to-moderate mental retardation: A review of the literature. Mental Retardation, 39(1), 20-31.

Gage, N. L., \& Berliner, D. C. (1992). Educational psychology (5th ed.). Boston, MA, US: Houghton, Mifflin and Company.

Heron, T. E., Villareal, D. M., Yao, M., Christianson, R. J., \& Heron, K. M. (2006). Peer tutoring systems:

Applications in classroom and specialized environments. Reading and Writing Quarterly: Overcoming Learning Difficulties, 22, 27-45

Jansen, B. R. J., Lange, E. De, \& van der Molen, M. J. (2013). Research in developmental disabilities math practice and its influence on math skills and executive functions in adolescents with mild to borderline intellectual disability. Research in Developmental Disabilities, 34, 1815-1824.

Kagohara, D. M., Sigafoos, J., Achmadi, D., van der Meer, L., O’Reilly, M. F., \& Lancioni, G. E. (2011). Teaching students with developmental disabilities to operate an iPod Touch ${ }^{\circledR}$ to listen to music.

Research in Developmental Disabilities, 32(6), 2987-2992.

Kazdin, A.E. (2013). Behavior Modification in applied settings $\left(7^{\text {th }}\right.$ ed.). Illinois:

Waveland Press.

Kementrian Kesehatan RI. (2014). Buletin Jendela : Data dan informasi kesehatan status penyandang disabilitas. Jakarta: Author.

Kern, L., Choutka, C. M., \& Sokol, N. G. (2002). Assessment-based antecedent interventions used in natural settings to reduce challenging behavior: An analysis of the literature. Education and Treatment of Children, 25(1), 113-130.

Kratochwill, T. R., Hitchcock, J., Horner, R. H., 
Levin, J. R., Odom, S. L., Rindskopf, D. M., \& Shadish, W. R. (2010). Single-case designs technical documentation.

Retrieved from

http://ies.ed.gov/ncee/wwc/pdf/wwc_scd.p df.

Mangunsong, F. (2009). Psikologi dan pendidikan anak berkebutuhan khusus jilid I. Jakarta: Lembaga Pengembangan Sarana Pengukuran dan Pendidikan Psikologi (LPSP3) Kampus Baru UI, Depok.

Martin, G., \& Pear, J. (2015). Behavior modification what it is and how to do it (10 ${ }^{\text {th }}$ ed.). New Jersey: Pearson

Education.

Miltenberger, R. G. (2012). Behavior modification $\left(5^{\text {th }} \mathrm{ed}\right.$.). Wadsworth: Cengage Learning.

Mirzamani, S. M., Ashoori, M., \& Sereshki, N. A. (2011). The effect of social and token economy reinforcements on academic achievement of students with intellectual disabilities. Iranian Journal of Psychiatry, 6(1), 25-30.

Mohsin, M. N., Khan, T. M., Doger, A. H., \& Awan, A. S. (2011). Role of parents in training of children with intellectual disability. International Ournal of Humanities and Social Sciences, 1(9), 7888.

Murray, S., Mitchell, J., Gale, T., Edwards, J., \& Zyngier, D. (2004). Student disengagement from primary schooling : A review of research and practice. Reterieved from http://dro.deakin.edu.au/view/DU:300407 71.

Pratiwi, I.C., Handayani, O.W.K., \& Raharjo, B.B. (2017). Kemampuan kognitif anak retardasi mental berdasarkan status gizi. Public Health Perspective Journal, 2(1), 19-25.

Schuiringa, H., van Nieuwenhuijzen, M., de Castro, B. O., \& Matthys, W. (2015). Parenting and the parent-child relationship in families of children with mild to borderline intellectual disabilities and externalizing behavior. Research in Developmental Disabilities, 36, 1-12.

Short, M. (2016). Increasing academic engagement through focused antecedent modification. Journal of curriculum and teaching, 5(2), 7-12.

Soemanto, W. (1998). Psikologi pendidikan.
Bandung: Rineka Cipta.

Sularyo, T.S., \& Kadim, M. (2000). Retardasi mental. Sari Pediatri, 2(3), 170 - 177. 